\title{
Do's \& don'ts for getting hotel deals done in the Russian/CIS markets
}

Received (in revised form): 5 September 2005

\section{Scott C. Antel}

is a partner in the Moscow office of DLA Piper Rudnick Gray Cary and has been working with the majority of international hotels and transactions in the Russian market for more than 12 years.

\author{
Abstract \\ The vast majority of international hotel transactions in the \\ Russian/CIS markets have been management/lease contracts \\ but this is changing and major acquisitions by international \\ operators/investors are set to flourish in the future as the \\ economies of these countries grows. Doing business in this \\ region can be a daunting prospect. Here, Scott Antel uses his \\ 12 years of experience to offer some useful do's and don'ts to \\ facilitate successful hotel transactions in this region.
}

\section{Keywords:}

international hotel deals, Russia, CIS

Journal of Retail and Leisure Property (2006) 5, 212-218. doi:10.1057/palgrave.rlp.5100013

\section{INTRODUCTION}

Many international investors take too much heed to Churchill's description of Russia being 'a riddle wrapped in a mystery inside an enigma' when negotiating international hotel deals in Russia and the CIS countries. The region is a different place to do business, no doubt. And then again it is not that different, certainly not so much that one should not behave in the same prudent business manner as they would back home.

In my 12 years of working with both hotel owners and operators in negotiating international management contracts, advising on day to day business and legal matters and the - to date quite limited - number of hotel acquisitions, I have witnessed - and indeed myself been guilty of - quite a number of less than constructive behaviour patterns when it came to closing hotel deals and retaining a good ongoing working relationship between owner and operator.

Below I summarise, from my composite experience, some of the key

Scott C. Antel

DLA Piper Rudnick Gray Cary Sadovnicheskaya Nab. 77

Moscow,

Russia 115035

Tel: + 70957559679

Fax: +70957832501

E-mail: scott.antel@dlapiper.com points for reaching closure and retaining the relationship in transactions in this market. I am guessing that quite a few of these points would equally apply to hotel transactions anywhere and are not necessarily Russia specific. However, this being a young and developing hospitality market (certainly one that virtually all the major international brands now regularly list as being number one or two on their development priority 
list), perhaps some of these, what should otherwise be relatively obvious, points are more exaggerated here.

I do not know if it is just in Russia, but the number one 'Run like the wind!' alarm to foreign operators - and I can't tell you how many times I have heard this! - is when the owner boasts of the roof-top restaurant to be (Moscow, St. Petersburg are low-rise cities) and that he has the interior design under control as his wife is handling that. I attribute this partly to the fact that owning hotels is often an 'ego business' (perhaps akin to owning a football club?), where an owner who has successfully developed a business empire in another sphere, through hard work and sound business judgement, suddenly chucks commercial reason out the window on the hotel project. Not always the case, but ego - and the common owner's feeling of an intuitive hospitality sense - does seem to be exaggerated in these projects.

To date, the vast majority of international hotel transactions in the Russia/CIS market have been management or - to a lesser extent - lease contracts, although that is beginning to change following one or two major acquisitions by international operators/investors and several more on the horizon. The equity trend is being further helped by, finally, both the Moscow and St Petersburg administrations' present serious attempts to properly appraise and put up for sale tender some of the remaining significant state-owned properties or land sites. ${ }^{1}$ Given, however, that most transactions one will encounter in this market are likely to be management/ lease arrangements, let us first start with this list of 'Dos' and 'Don'ts'.

\section{Do leave the arrogance back home}

This is important from the international operator's side. While it is true that most Russian owners will have even far less knowledge of the hospitality business, and what it takes to make a property successful, than perhaps owner's elsewhere, Russians do learn quickly and are smarter than they may appear (particularly in the chess game of business negotiations).

\section{Do spend the time to explain what an international operator does}

Do spend the time to explain what an international operator does and what they bring to the table and what value they can, and will continue to, bring to the property. Simply saying 'If you read the agreements, you will see what we do' is not enough, as these - even reading through all the disclaimers and other rhetoric — frankly do not tell a whole lot about what an international operator does. Show them the value and always remember that the international operator will need to continue doing so because (here the ego thing returns) a hotel looks a lot easier to run than it is in reality and they may get the idea that they can run it themselves. And, as discussed further on, an operator's legal recourse in such a case may be far more limited than elsewhere.

\section{Do not think the standard management agreements or structure will work}

Don't think the standard management agreements or structure will work in Russia, because they will not. Both the operator and the owner will 
suffer for it: the owner not being able to deduct the fees paid to the operator and the latter not being able to receive their funds or, if they can, with a unnecessary delay or withholding tax cost that could otherwise have been avoided with proper planning. Probably one-third of my hotel work has been spent 'Russifying' previously wrongly drafted or structured agreements, usually 'imported' from use elsewhere, and which posed significant tax risks to both the owner and operator and delayed the operator from promptly receiving its funds. Get proper advice in advance and get it right the first time round. The results can be very favourable — indeed winwin for both parties - including the potential for the foreign operator to avoid any local registered presence or incur any Russian tax whatsoever.

\section{Do retain experienced locally based advisors}

On this same note, do retain experienced locally based advisors who know the law, the hotel industry and how the international operators have practically gotten to where they are today insofar as how the hotel industry operates in the market. Failure to do so will get the transaction well off track and outside the norms that have developed in the market. As a perceived affluent industry that is generally highly scrutinised by the tax and other authorities, going solo in our own structural approach can prove costly.

\section{Do not let the lawyers/advisors take over}

At the same time, do not let the lawyers/advisors take over the negotiations and turn them into a legal battle that disregards the underlying business context and potentially destroys the working relationship. This is a long-term marriage (typically 15 years or more) and it is good to get started on the right foot. Numerous times I have seen inexperienced hotels counsel for both sides focus on the wrong points and extend the negotiations, or poison the relationship, by hammering on the wrong points when they could have forged a better deal for their client and both parties if they had better understood the role of the international operator.

\section{Do not take advantage of your superior industry knowledge}

Don't take advantage of your superior industry knowledge. I have seen several international operators try and convince the owner to shun all outside advisors in the negotiations and drafting stages, suggesting they only get in the way, are expensive (true) and unnecessary (not true). In reality the operator was trying to take advantage of the tendency of many Russian businesses to eschew use of external advisors and to exploit the owner's clear lack of experience regarding management agreement terms, what is/is not included in GOP, etc, and what were acceptable operator fee levels in the market for the product. In several cases, this backfired early on when the owners realised they were being pressureised to sign a contract they did not understand and after legal advisors were called in to explain the inequity of the situation. The owners walked away and swore never to deal with that operator again, despite their having several properties in well-advanced stages of discussion with that operator.

The same point is made to avoid taking advantage of their local knowledge when working with Russian owners, pointing out that a hotel 
management agreement is in many respects a 'joint venture' relationship depending on the trust and mutual working relationship throughout for the deal in order for both parties to prosper. The importance of retaining the relationship is important anywhere, but may be even more so in Russia, since, as a practical matter, if the owner wants the operator out, they are gone irrespective of protective contract terms. Under Russian law, a service (management) contract is terminable at will by the owner who need to only pay up the amounts that are outstanding plus some nominal notice fee to quit. One can potentially avoid this legal loop hole by choosing foreign law, or by adopting a lease or other non-service agreement, but as a practical matter, if the relationship has soured to this point, there is little the foreign operator can do to salvage the situation or try to enforce the agreement or seek damages for the remainder of the term.

Moving to the less frequent but, as noted, growing trend for hotel property acquisition transactions, it is probably fair to say that most of the those Dos and Don'ts already cited above for management lease negotiations equally apply to asset deals. Thus, keeping those in mind, let us address some points specific to hotel acquisition projects in Russia/ CIS.

\section{Do not believe all that is told about a property}

Do not believe all that is told about a property. The level and quality of bookkeeping, inventory lists, operational performance information, etc, is not likely to be what one would expect for a property in a more developed jurisdiction, particularly if the target has not previously had any foreign operator management. Even then, Russians are very hesitant to open up their books and records to outsiders at the best of times and often simply do not see the need or understand the foreign buyer's insistence on responding to a long due diligence questionnaire. There is a tendency to believe that one takes it as he sees it and to reject notions of 'reps and warranties' and purchase price holdbacks. Sign the deal, give us our money and let us be done with it; obviously, that is not how most international investors look at such property transactions, and it will be necessary to explain to the sellers that the buyer as a matter of company policy must undertake the necessary due diligence to make the case to their board and obtain deal approval. Thus, the motto should be 'trust but verify' with thorough due diligence.

\section{Don't expect clear title}

Don't expect clear title to the property. It would be rare indeed to find a property that does not have some title skeletons stemming back to initial problems in the privatization process and or the privatization legislation itself. Further along the title chain there may well be issues with respect to prior acquisitions by private investors. It is not uncommon to find essential documentation proving the validity of transfers also missing. I know of one instance with a colleague in a non- hotel property transaction where upon presenting the owner with a list of more than ten serious title effects he received the response; 'What are you talking about. This is the 
cleanest property we have' part of the rules of the game and an element of the Russian risk factor that needs to be factored in to, and properly planned, for in any transaction. If one cannot accept that risk, there is a good chance of being foreclosed from this market.

\section{Do expect complicated structures}

Do expect complicated structures. This partly goes back to the mystery surrounding ownership, title, etc, but it will be common for the property to be held in a Russian company by an offshore special purpose vehicle (SPV) with ownership further up the chain held via various nominee shareholders in jurisdictions that do not require identification of the beneficial owners. Typically the property will be dropped into a Russian newco, which will be sold to the foreign SPV at a cost equal to or slightly above its tax basis. The acquirer then purchases the SPV owning the Russian newco holding the hotel asset paying the real market value offshore and outside the Russian tax net. Often this will be the only way the seller is willing to structure the deal and one is left with a 'take the structure or leave it' situation. While, as noted this is common in the Russian market and, to a lesser extent, somewhat common for real estate transactions in more developed jurisdictions, one needs to keep in mind the Russian tax authorities' growing sophistication in international transactions. While historically the authorities have applied a 'form over substance' analyses to their review of transactions, thus allowing for multiple step transactions to minimise or altogether avoid tax, their is a growing understanding and application of substance-based approach. Thus, while the structure proposed may not be as simple as one might like, Do not believe that all Russian deals involve tax evasion. Increasing sophistication of the authorities, combined with increasing demands for transparency (and relatively low Russian tax rates -24 per cent) means that increasingly more of the consideration paid-in transactions will be onshore.

\section{Don't expect the sellers to be experienced in international transactions and their complexities}

Don't expect the sellers to be experienced in international transactions and their complexities. 'What do you mean reps and warranties? Don't you trust us?' There will be resistance to the level of complexity normally required to be contained in any share purchase agreement for such an asset. Also, a reluctance to provide and/or likely delays in responding to, or incomplete, due diligence requests for information, this going back to the secrecy tendencies noted earlier.

\section{Do insist on the sellers retaining experienced counsel}

It can certainly help the position of international operators if they do insist on the sellers retaining experienced counsel, who can then, hopefully, explain to the seller's the rationale behind the demands for due diligence information and seeking certain reps and warranties. This can also speed along the negotiations process if the seller's counsel can explain the need for and initiate prompt disclosure of information. It can 
also save the buyer time and money by partly removing the need of the buyer's counsel to carry out many of the tasks that should otherwise be undertaken by the seller or seller's counsel.

\section{Do a 'turnkey' purchase transaction}

Do a 'turnkey' purchase transaction where the international operator can, leaving it the seller's responsibility to deliver the property with all operating licenses, minority share interests, underlying land or other interests obtained by them prior to completion using their political connections. This can certainly make things much easier and is worth paying a purchase premium for or incentivising them to undertake by way of a purchase price holdback until such items are completed. They know the system better than the operator and likely have the political connections that the operator does not. Also, they are more likely to get a better deal than when the 'deep pocketed' foreign investor seeks these things later on.

\section{Do not believe in finding a property through brokers or agents} Do not believe in finding a property through brokers or agents. While certain properties may be offered through the normal broker or listed channels, many of the more attractive options will only be found via word of mouth, pounding the street and/or going directly to existing owners and offering them a deal they cannot refuse. Today's real estate market provides existing owners a very healthy cash flow on their real estate investments, not to mention significant asset appreciation, which leaves many owners in no hurry to sell. Also, those that are listed are likely to have already been picked over and been rejected due to the asking price or other reasons. If the operator can do his own legwork and research, chances are he is in to find a better deal.

\section{Do be ready to move quickly}

Do be ready to move quickly once a property has been identified.

Particularly for Moscow, St Petersburg and certain other select cities, this is indeed a seller's market with a shortage of attractive properties or sites. Delaying to long in negotiations and due diligence may result in the operator doing, and paying for, the advance work for another buyer.

\section{Do not jump too fast}

However, do not jump too fast. This is a classic negations trick of dubious sellers pressing the buyer with false deadlines to close the deal. While it is always advantageous for a party to set the pace and, thereby, control the agenda to some extent, it is important to recognise that transaction time frames are much longer in Russia. This is due to the already noted lack of international transaction sophistication, often times absence of experienced seller counsel and hesitance to disclose information, as well as certain cultural elements including language differences and the need for translations, breaking down cultural misperceptions and distrust and other such factors. Thus one needs to plan a transaction timetable taking 
longer that is longer than the ordinary and for the negotiations to cost more.

\section{Do behave like one would back home}

Finally on this point, and returning to the initial recommendation in the discussion of negotiating management agreements, do behave like one would back home, insisting on and undertaking thorough due diligence, thoroughly preparing and reviewing the contracts and insisting on following the law. As noted, Russia is a different negotiating environment, but not that different to forgo proper business prudence. And while Russia undoubtedly has a less formal legalistic approach to transactions, this does not mean that one has to close a deal simply by toasting vodka shots and doing male bonding in a banya (sauna).

Much of what I have noted would indeed appear so obvious, but from my experience many otherwise rationale and highly competent investors do indeed get caught up in the myth of commercial mystery and informality that is frequently associated with the region. While any successful investment into this regions will undoubtedly involve a level of country risk associated with historical deficiencies in title, privatization laws and the potential interpretation and/or application of the existing commercial code and laws, those who are prepared to do the advance work and properly plan to mitigate, or at least minimise, those risks, stand to occupy a market that has only just begun to address its upside. Just to take Moscow as an example: a capital city of 11 million people with a rapidly expanding international business economy and only about 5,000 western standard hotel rooms. These days - and likely for some time in the future in this market - it is good to be in the hotel business.

\section{Note}

1 The Russian Constitution, Civil Code and Land Code generally allow for the possibility for foreign interests to purchase Russian real estate objects as well as the land underneath them, although Moscow claims an exception to these rules and only provides for procedures for lease of the underlying land usually of 49 or 99 years. 